\title{
Evaluation of Blood Gas Analysis as a Mortality Predictor
}

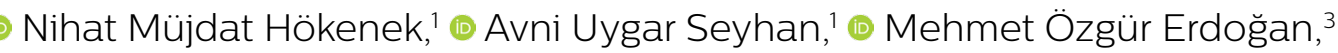

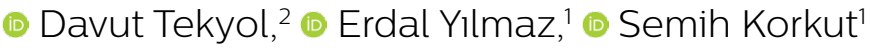

\footnotetext{
'Department of Emergency Medicine, University of Health Sciences, Kartal Dr. Lütfi Kırdar Training and Research Hospital, İstanbul, Turkey

${ }^{2}$ Department of Emergency Medicine, University of Health Sciences, Haydarpaşa Numune Training and Research Hospital, İstanbul, Turkey

3Department of Emergency Medicine, University of Bahçeşehir Göztepe Medical Park Hospital, İstanbul, Turkey

Submitted: 08.04.2019 Accepted: 28.06.2019

Correspondence: Nihat Müjdat Hökenek, Sağlık Bilimleri Üniversitesi, Acil Tıp Anabilim Dalı, Kartal Dr. Lütfi Kırdar Eğitim ve Araştırma Hastanesi, İstanbul, Turkey

E-mail: nihathokenek@gmail.com

Keywords: Base excess; blood gas; lactate; mortality.

\begin{abstract}
Objective: This study examines the effects of the blood gas analysis on mortality. This method may contribute to decreasing mortality rates in intensive care wards and emergency rooms.
\end{abstract}

Methods: The study uses the data that was retrospectively derived and analyzed from patients who were admitted to Haydarpasa Numune Education and Research Hospital Emergency Room between January 2016-January 2017. Two hundred seventy-four patients added to this study, and the data were taken from the patient's first blood gas analysis.

Results: Our study showed us lactate, base excess, bicarbonate levels can have a relation with mortality. Statistical analysis for lactate had $4.64 \pm 4.696 \mathrm{mEq} / \mathrm{L}$ values, and it was significant for mortality in the non-survival group $(p=0.000)$. In the ROC analysis of the lactate, the area under the curve was determined as 0.725 , and when the lactate was above 1.5 $\mathrm{mEq} / \mathrm{L}$, it had $76 \%$ sensitivity and $54 \%$ specificity. In the non-survivor group (mean $\pm \mathrm{SD}$ ) $-5.57 \pm 9.852 \mathrm{mmol} / \mathrm{L}$ values for the base deficit was found to be meaningful in terms of mortality $(p=0.000)$. The area under the curve was 0.726 as a result of the ROC analysis of the base excess, with a sensitivity of $63 \%$ and a specificity of $74.7 \%$ for the value of $-2.5 \mathrm{mmol} / \mathrm{L}$. The statistics for bicarbonate (mean \pm SD) $19.63 \pm 7.725 \mathrm{mmol} / \mathrm{L}$ range values are significant as predictors of mortality $(p<0.05)$. In our study, $62 \%$ mortality was observed in the baseline values of $-2 \mathrm{mmol} / \mathrm{L}$ and below for base excess, and it was found to be a significant predictor of mortality. The other parameters, $\left(\mathrm{pH}, \mathrm{PCO}_{2}, \mathrm{PaO}_{2}\right)$, were not statistically significant as a mortality predictor $(\mathrm{p}>0.05)$.

Conclusion: As a result of the data obtained in our study, the findings suggest that the values of lactate, bicarbonate and base deficit could be the predictors of mortality.

\section{INTRODUCTION}

As a result of increasing life expectancy, the prevalence of the chronic disease, and technological development, the number of patients who need to be treated in the intensive care unit is becoming higher day by day. ${ }^{[1]}$

The survival rates of these patients were directly proportional to the frequency of their early diagnosis and treatment. ${ }^{[2]}$ In this sense, the emergency department should be the place where diagnosis and treatment are administered as fast as possible. Given that blood gas is the first laboratory parameter to reach us has led to the necessity of evaluating it as a mortality predictor. Base excess levels provide information about the perfusion ability of the tissue and the need for resuscitation. These values pro- vide a piece of objective information about the patient's condition. In this study, blood gas analysis of 274 patients who were transferred to the emergency department from the intensive care unit was evaluated. The relationship between blood gas analysis and mortality was investigated. In this study, we aim to measure the acceptability of base excess, lactate and bicarbonate values as a predictor of mortality.

\section{MATERIALS AND METHODS}

In this study, blood gas analysis of 274 patients who were transferred to the intensive care unit from the hospital emergency department was evaluated. The data were taken between January 2016 to January 2017 retrospectively. 
All patients were seen by the emergency department. Patients diagnosed and treated according to the current protocols, and then transferred to ICU. Blood gas analysis results were taken from the hospital archive. Patients were divided into two groups as survivors and non-survivors. The parameters analyzed from the records were the age, gender, history of application, arrival arterial blood gas, $\mathrm{PaO}_{2}, \mathrm{PaCO}_{2}, \mathrm{HCO}_{3}$, lactate, base excess, and mortality. The student t-test was used for parametric data, and data analysis was performed using chi-square tests for nonparametric data. $\mathrm{p}<0.05$ was accepted as statistically significant. Also, the Receiver Operating Characteristic (ROC) curve was used to find the true positive rate (Sensitivity) and the false positive rate (100-Specificity) for different cut-off points. ROC was used for base excess and lactate (Figs. I and 2).

\section{Inclusion criteria}

Patients who were older than 17 years, prognosed as sepsis by "International Guidelines for Management of Sepsis and Septic Shock 2016 Guideline"' rules, hypotension, need for intensive care unit admission were included in this study.

\section{Exclusion criteria}

Patients who had cardiopulmonary resuscitation at the time of appointment to the emergency room, chronic kidney diseases (CKD), patients with acute gastroenteritis and age below 17 years were excluded from this study.

\section{RESULTS}

This study included 274 patients first admitted to the emergency department and then to the intensive care unit. One hundred and seventy-four (63.5\%) of the patients examined in this study survived and 100 (36.4\%) patients died. Forty-one of our patients had chronic obstructive pulmonary disease. No significant results were

Table I. Relation between mortality and COPD, CHF and sepsis

\begin{tabular}{lccc}
\hline Variables & $\begin{array}{c}\text { Survivors } \\
\mathbf{n}(\%)\end{array}$ & $\begin{array}{c}\text { Non-survivors } \\
\mathbf{n}(\%)\end{array}$ & $\mathbf{p}$ \\
\hline COPD & & & \\
COPD negative & $144(82.75)$ & $85(85.00)$ & \\
COPD positive & $30(17.24)$ & $15(15.00)$ & 0.735 \\
CHF & & & \\
CHF negative & III (63.79) & $45(45.00)$ & \\
CHF positive & $63(36.21)$ & $55(55.00)$ & 0.003 \\
Sepsis & & & \\
Sepsis negative & $15 \mathrm{I}(86.78)$ & $80(80.00)$ & \\
Sepsis positive & $23(13.22)$ & $20(20.00)$ & 0.222 \\
Total & 174 & 100 & \\
\hline
\end{tabular}

COPD: Chronic obstructive pulmonary disease, CHF: Chronic heart failure. found in the relationship between the presence of COPD and early mortality in statistical analysis $(p=0.735)$. When the relationship between heart failure and early mortality was evaluated in 118 patients with heart failure, a significant result was found $(p=0.003)$. When the patients with sepsis were screened, 42 patients were seen, but the relationship between sepsis and early mortality was found to be negative $(p=0.222)$ (Table $I)$.

The laboratory parameters of blood gas and the relationship of APACHE scoring with mortality were examined in detail in Table 2. In the group with mortality, 69.87 \pm 16.764 for age, 19.63 \pm 7.725 for $\mathrm{HCO}_{3}, 4.64 \pm 4.696$ for lactate and $-5.57 \pm 9.852$ for base excess were found to be significantly associated with early mortality.

In the non-survivor group, for ph $7.0524 \pm 0.723, \mathrm{PaO}_{2}$, $98.6 I \pm 56.72, \mathrm{PaCO}_{2}$, and $43.24 \pm 18.81 \mathrm{I}$ values were determined. These values had no correlation with early mortality.

The findings showed that the base excess was a successful parameter as a predictor of mortality in the roc curve.

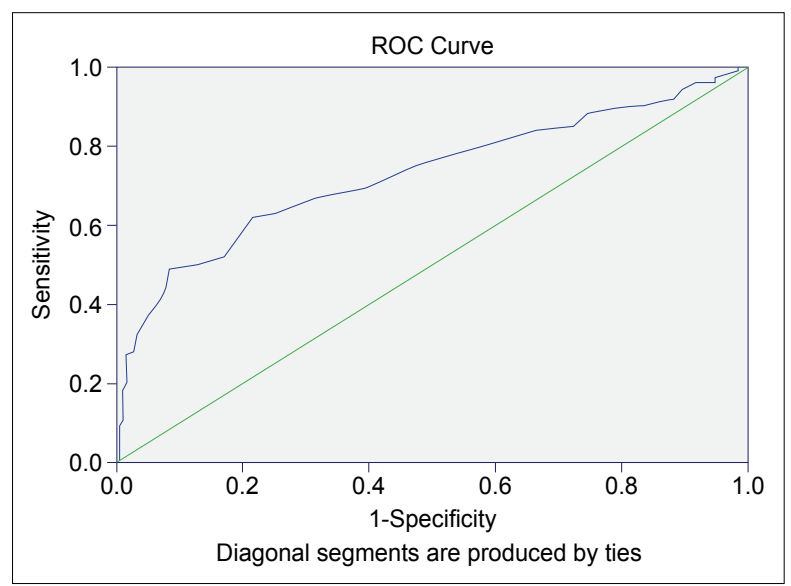

Figure 1. ROC curve for base excess.

Table 2. Relation between survivors and non-survivors patients according to laboratory predictors and $\mathrm{APACHE}_{2}$ scores

\begin{tabular}{lccc}
\hline Variables & $\begin{array}{c}\text { Survivors } \\
\text { (Mean } \pm \text { SD) }\end{array}$ & $\begin{array}{c}\text { Non-survivors } \\
\text { (Mean } \pm \text { SD) }\end{array}$ & $\mathbf{p}$ \\
\hline $\mathrm{Age}$ & $63.47 \pm 21.615$ & $69.87 \pm 16.764$ & 0.001 \\
$\mathrm{Ph}$ & $7.1436 \pm 0.55$ & $7.05244 \pm 0.723$ & 0.210 \\
$\mathrm{PaO}_{2}$ & $103.18 \pm 71.247$ & $98.61 \pm 56.72$ & 0.487 \\
$\mathrm{PaCO}_{2}$ & $43.06 \pm 15.431$ & $43.24 \pm 18.81 \mathrm{I}$ & 0.175 \\
$\mathrm{HCO}_{3}$ & $25.86 \pm 6.58$ & $19.63 \pm 7.725$ & 0.004 \\
Lactate $_{\text {APACHE }}$ & $1.85 \pm 1.7$ & $4.64 \pm 4.696$ & 0.000 \\
$\mathrm{BE}$ & $19.25 \pm 7.754$ & $27.50 \pm 7.453$ & 0.402 \\
Total & $1.71 \pm 7.717$ & $-5.57 \pm 9.852$ & 0.000 \\
\hline
\end{tabular}

BE: Base excess; $\mathrm{APACHE}_{2}$ : Acute physiology and chronic health evaluation; $\mathrm{PaO}_{2}$ : Partial pressure of arterial oxygen; $\mathrm{PaCO}_{2}$ : Partial pressure of arterial carbon dioxide. 
Table 3. Cause of death in the non-survival group

\begin{tabular}{lcc}
\hline Cause of death & Frequency & Percent \\
\hline Pneumonia & 23 & 23.00 \\
Sepsis & 14 & 14.00 \\
Acute coronary syndrome & 13 & 13.00 \\
Lung edema & 12 & 12.00 \\
Chronic obstructive lung disease & 11 & 11.00 \\
Malignancy & 12 & 12.00 \\
Pulmonary thromboembolism & 7 & 7.00 \\
Acute hepatic failure & 5 & 5.00 \\
Serebrovascular event & 3 & 3.00 \\
Total & 100 & 100 \\
\hline
\end{tabular}

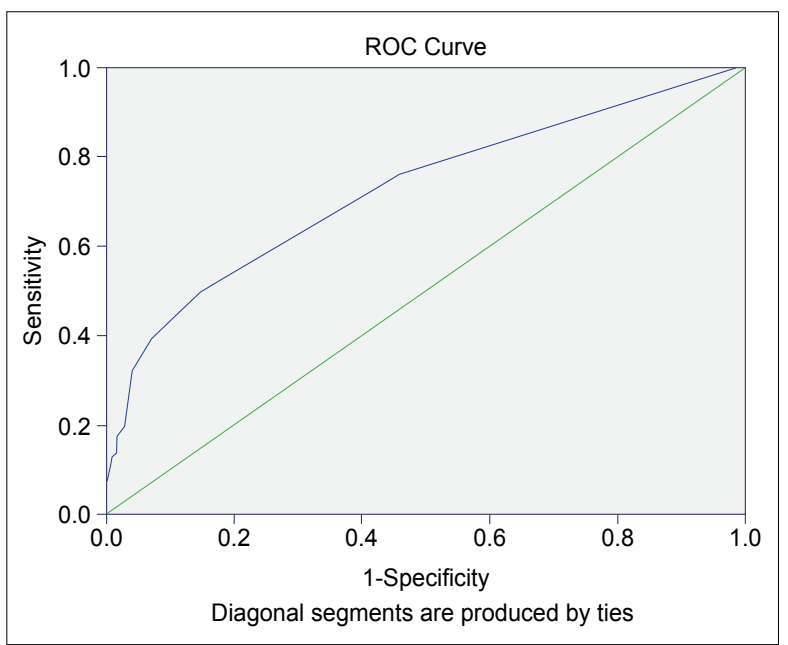

Figure 2. ROC curve for lactate.

The area under the curve was 0.726 . A sensitivity of $63 \%$ and a specificity of $74.7 \%$ were determined for the value of $-2.5 \mathrm{mmol} / \mathrm{L}$.

In the ROC analysis for the lactate, the area under the curve was determined as 0.725 . Lactate value higher than $1.5 \mathrm{mEq} / \mathrm{L}$ was found to have $76 \%$ sensitivity and $54 \%$ specificity for determining early mortality.

Causes of death in the non-survival group was pneumonia, sepsis, acute coronary syndrome, lung edema, chronic obstructive pulmonary disease, pulmonary thromboembolism, acute hepatic failure, serebrovascular event and malignancy was seen significantly (Table 3).

Length of stay of the non-survival group in ICU was $424.19 \pm 289.663$ minutes $(\min 86, \max 1523$ ). For the survivor group length of stay in ICU was $352.83 \pm 332.5$ I 4 minutes ( $\min 31, \max 2370)$.

\section{DISCUSSION}

The identification of critically ill patients is not always easy. If these patients can be diagnosed quickly, the process can be recovered while it is reversible. Heart rate, blood pressure, urine output and peripheral perfusion, which are among the traditional follow-up findings of resuscitation, are not sensitive indicators of physiological deterioration. ${ }^{[1-3]}$ Therefore, many researchers have used various parameters to predict patient deterioration, including physiological scoring systems, hemodynamic variables and their response to treatment. This study aimed to evaluate the relationship between blood gas analysis with mortality.

The base excess can be defined as the amount of base in mmol required to bring $\mathrm{I} \mathrm{L}$ of arterial blood $\mathrm{pH}$ to 7.40. Base excess has been shown to be superior to $\mathrm{pH}$ in predicting clearance of metabolic acidosis and predicting subsequent complications. ${ }^{[5]}$ The correlation of base excess with the mortality and need for intravascular fluid replacement therapy in patients with traumatic, hypovolemic shock, hepatic and pelvic injury has been shown previously. ${ }^{[6-9]}$ The relationship between hypovolemia and base excess can be associated with tissue perfusion and hypoxia. Given that base excess is above $-6 \mathrm{mmol} / \mathrm{L}$ in severe trauma patients has a significant relationship with serious injury and mortality. ${ }^{[5-10]}$

In a study, authors divided the base excess into three categories as mild (3-5 mmol/L), milder $(6-14 \mathrm{mmol} / \mathrm{L})$ and severe (more than $15 \mathrm{mmol} / \mathrm{L}$ ) ${ }^{[8,9]}$ They tried to determine the level of fluid resuscitation needed according to this classification. However, another study showed a mortality rate of $57.1 \%$ in patients with baseline deficit above $-4 \mathrm{mmol} / \mathrm{L}$. In our study, $62 \%$ mortality was found in the baseline values of $-2 \mathrm{mmol} / \mathrm{L}$ and below, and the base excess appears to be a predictor of mortality. In general clinical use, the base gas gap is automatically given in blood gas. It is, therefore, easily accessible. Our study defines a population with a mortality rate of $62 \%$ if a negative baseline value is used as a prognostic marker. As a result, 62 of 100 patients whose base excess was less than $-2 \mathrm{mmol} / \mathrm{L}$ remained mortal.

Another significant result of our study was the relationship between lactate values and mortality. Lactate is formed from pyruvate in tissues where glycolysis is at high speed as a result of anaerobic glycolysis. Tissue, skeletal, muscle, skin, brain and erythrocytes are the tissues with high glycolysis rates and account for 50 percent of lactic acid formation. Generally, the lactate level is below I meq/l. Oxidation via Krebs cycle or gluconeogenesis in the liver provides lactate metabolism. The kidneys also metabolize 30 percent of lactate. The lactate level in lactic acidosis is at least 4-5 meq/lt. Often it is between $1-30 \mathrm{meq} / \mathrm{lt}$. In our study, the lactate value was observed as one of the predictors of mortality, and results were consistent with the literature.

Lactate and base excess were associated with $\mathrm{APACHE}_{2}$ score increase in our study and suggested that it could contribute to the prediction of mortality. Based on this result, it was suggested that a scoring system that includes biochemical markers and vital parameters could be created. A new mortality prediction system that contains more biochemical and objective data can have more accuracy on foreseeing the survival. Our study is not designed for this purpose, and further studies are needed on this subject. 
Ethics Committee Approval

All procedures performed in studies involving human participants were in accordance with the ethical standarts of the institutional and/or national research committee and with 1964 Declaration of Helsinki and its later amendments or comparable ethical standarts.

\section{Informed Consent}

Retrospective study.

Peer-review

Internally peer-reviewed.

Authorship Contributions

Concept: M.Ö.E., D.T. E.Y.; Design: S.K., A.U.S.; Supervision: N.M.H., S.K., D.T.; Fundings: None; Materials: None; Data: M.Ö.E., A.U.S., S.K.; Analysis: N.M.H., S.K., D.T.; Literature search: N.M.H.; Writing: N.M.H., A.U.S., E.Y.; Critical revision: E.Y., M.Ö.E.

Conflict of Interest

None declared.

\section{REFERENCES}

1. Zimmerman JE, Kramer AA, McNair DS, Malila FM. Acute Physiology and Chronic Health Evaluation (APACHE) IV: hospital mortality assessment for today's critically ill patients. Crit Care Med
2006;34:1297-310. [CrossRef]

2. Davis JW. The relationship of base deficit to lactate in porcine hemorrhagic shock and resuscitation. J Trauma 1994;36:168-72. [CrossRef]

3. Parker MM, Shelhamer JH, Natanson C, Alling DW, Parrillo JE. Serial cardiovascular variables in survivors and nonsurvivors of human septic shock: heart rate as an early predictor of prognosis. Crit Care Med 1987;15:923-9. [CrossRef]

4. Bernardin G, Pradier C, Tiger F, Deloffre P, Mattei M. Blood pressure and arterial lactate level are early indicators of short-term survival in human septic shock. Intensive Care Med 1996;22:17-25. [CrossRef]

5. Davis JW, Kaups KL, Parks SN. Base deficit is superior to $\mathrm{pH}$ in evaluating clearance of acidosis after traumatic shock. J Trauma 1998;44:114-8. [CrossRef]

6. Siegel JH, Rivkind AI, Dalal S, Goodarzi S. Early physiologic predictors of injury severity and death in blunt multiple trauma. Arch Surg 1990;125:498-508. [CrossRef]

7. Dunham CM, Siegel JH, Weireter L, Fabian M, Goodarzi S, Guadalupi P, et al. Oxygen debt and metabolic acidemia as quantitative predictors of mortality and the severity of the ischemic insult in hemorrhagic shock. Crit Care Med 1991;19:231-43. [CrossRef]

8. Davis JW, Shackford SR, Holbrook TL. Base deficit as a sensitive indicator of compensated shock and tissue oxygen utilization. Surg Gynecol Obstet 1991;173:473-6.

9. Davis JW, Kaups KL. Base deficit in the elderly: a marker of severe injury and death. J Trauma 1998;45:873-7. [CrossRef]

10. Davis JW, Mackersie RC, Holbrook TL, Hoyt DB. Base deficit as an indicator of significant abdominal injury. Ann Emerg Med 1991;20:842-4. [CrossRef]

\section{Mortalite Prediktörü Olarak Kan Gazı Analizinin Değerlendirilmesi}

Amaç: Bu çalışma kan gazı analizinin mortalite üzerindeki etkilerini incelemektedir. Bu yöntem yoğun bakımlarda ve acil servislerde mortalite oranlarının azaltılmasına katkıda bulunabilir.

Gereç ve Yöntem: Çalışma verileri Ocak 2016-Ocak 2017 tarihleri arasında Haydarpaşa Numune Eğitim ve Araştırma Hastanesi Acil Servisi'ne getirilen hastalardan geriye dönük olarak edinildi ve analiz edildi. Bu çalışmaya 274 hasta alındı, hasta verileri acil servis başvurularındaki ilk kan gazı kayıtlarından alındı.

Bulgular: Çalışmamız bize laktat, baz açı̆̆ı ve bikarbonat düzeylerinin mortalite ile ilişkili olabileceğini gösterdi. Laktat için istatistiksel analiz sağkalım olmayan grupta $4.64 \pm 4.696 \mathrm{mEq} / \mathrm{L}$ değerlerine sahipti ve mortalite açısından anlamlıydı $(p=0.000)$. Laktatın ROC analizinde, eğri altındaki alan 0.725 olarak belirlenmiştir. Laktat $1.5 \mathrm{mEq} / \mathrm{L}$ 'nin üzerinde olduğunda, \%76 duyarlılığa ve \%54 özgüllüğe sahiptir. Hayatta kalan grupta (ortalama $\pm S S$ ), baz açı̆̆ı için $-5.57 \pm 9.852 \mathrm{mmol} / \mathrm{L}$ değerlerinin mortalite açısından anlamlı olduğu bulundu $(\mathrm{p}=0.000)$. Eğri altındaki alan, baz açığı için, $-2.5 \mathrm{mmol} / \mathrm{L}$ değerinde ROC analizi sonucunda 0.726 bulundu. Bu değerin \%63 duyarlılık ve \%74.7 özgüllüğe sahip olduğu tespit edildi. Bikarbonat için (ortalama $\pm S S$ ) $19.63 \pm 7.725 \mathrm{mmol} / \mathrm{L}$ aralığı değerleri mortalitenin prediktörü olarak anlamlı bulundu ( $p<0.05$ ). Çalışmamızda baz açığı için $-2 \mathrm{mmol} / \mathrm{L}$ ve altındaki bazal değerlerde $\% 62$ mortalite gözlendi ve mortalitenin anlamlı bir prediktörü olduğu bulundu. Diğer parametreler $\left(\mathrm{pH}, \mathrm{PCO}_{2}, \mathrm{PaO}_{2}\right)$ mortaliteyi tahmin etmede anlamlı bulunmadı $(\mathrm{p}>0.05)$.

Sonuç: Çalışmamızda elde edilen veriler sonucunda laktat, bikarbonat ve baz açığı değerlerinin mortalite prediktörü olabileceği belirlenmiştir.

Anahtar Sözcükler: Baz açı̆̆; kan gazı; laktat; mortalite. 